\title{
Korelasi Antara Parameter Indeks Plastisitas dengan Sudut Geser Tanah Dengan Penambahan Kapur Terhadap Stabilisasi Daya Dukung Pondasi Dangkal
}

\section{Correlation Between Plasticity Index Parameters and Ground Shear Angle With Addition of Chalk To Stabilization Carrying Capacity of Shallow Foundations}

\author{
Nur Andajani ${ }^{1}$, Arik Triarso ${ }^{2}$ \\ ${ }^{1}$ Jurusan Teknik Sipil, Fakultas Teknik, Universitas Negeri Surabaya, Jln. Ketintang Surabaya. Email : \\ nurandajani@unesa.ac.id \\ ${ }^{2}$ Jurusan Teknik Sipil, Fakultas Teknik, Universitas Negeri Surabaya, Jln. Ketintang Surabaya. Email : \\ ariktriarso@unesa.ac.id
}

\begin{abstract}
Abstrak
Tanah di salah satu daerah di Mojokerto tepatnya di wilayah kecamatan "Dawarblandong” mempunyai kecenderungan memiliki sifat yang kurang baiksehingga diperlukan adanya stabilisasi yaitu dengan memberikan material tambahan untuk meningkatkan daya dukungnya. Material kapur dapat digunakan sabagai bahan campuran untuk stabilisasi. Pengujian tanah dilakukan untuk mengetahui karakteristik tanah adalah uji konsistensi tanah yang menghasilkan parameter batas cair (LL), batas plastis (PL), dan indeks plastisitas (IP). Uji directh shear dan unconfineddilakukan menghasilkan sudut geser tanah ( $\phi)$, dan cohesi (c). Hubungan atau korelasi antara parameter plastisitas tanah dengan parameter sudut geser tanah dan cohesidapat diperoleh dari hasil analisa pengujian tersebut. Dari hasil penelitian ini menunjukan bahwa semakin besar Indeks Plastisitas tanah (IP), maka akan semakin kecil nilai kohesi tanahnya (C) dan akan semakin besar pula harga sudut geser tanahnya ( $\phi)$.Pada penambahan 10\% kapur nilai LL menurun sebesar 13.03\%. Demikian pula semakin besar persentase kapur yang ditambahkan, maka nilai Indeks Plastisitas (IP) semakin menurun. Pada penambahan 10\% kapur nilai IP menurun sebesar 24.52\%.Adanya stabilisasi dengan 10\% kapur pada tanah lempung ekspansif di daerah mojokerto menyebabkan nilai kohesi dari tanah meningkat, maka hal ini dapat mengakibatkan stabilitas daya dukung pondasi dangka di daerah Mojokerto tersebut juga akan meningkat.
\end{abstract}

Kata Kunci: Indeks plastis, sudut geser, stabilitas daya dukung

\begin{abstract}
Land in one of the areas in Mojokerto precisely in the "Dawarblandong" sub-district has a tendency to have unfavorable characteristics so that there is a need for stabilization by providing additional material to increase its carrying capacity. Lime material can be used as a mixture for stabilization. Soil testing is carried out to determine the characteristics of the soil is a soil consistency test that produces the parameters of the liquid limit $(L L)$, plastic limit (PL), and plasticity index (IP). Direct shear and unconfined tests were carried out to produce ground shear angle $(\phi)$, and cohesion (c). The relationship or correlation between soil plasticity parameters and soil shear angle parameters and cohesion can be obtained from the results of the test analysis. The results of this study indicate that the greater the Soil Plasticity Index (IP), the smaller the soil cohesion value (C) and the greater the soil shear angle $(\phi)$. In addition of $10 \%$ lime the LL value decreases by $13.03 \%$. Likewise, the greater the percentage of lime added, the value of the Plasticity Index (IP) decreases. On the addition of $10 \%$ lime, the IP value decreased by $24.52 \%$. The stabilization with $10 \%$ lime on the expansive clay in the mojokerto area caused the cohesion of the soil to increase, so this could result in stability of carrying capacity of the dangka foundation in the Mojokerto area.
\end{abstract}

Keywords: Plastic index, shear angle, carrying capacity stability 


\section{PENDAHULUAN}

Perkembangan kawasan di mojokerto semakin cepat, hal ini dapat dilihat dari semakin banyaknya lahan yang dibuka dan akan digunakan sebagai area kawasan permukiman dan aktifitas ekonomi lainnya. Pembangunan kawasan tersebut meliputi perumahan, pertokoan, perkantoran, gedung fasilitas umum, infrastruktur jalan, saluran, dan lain - lain. Dalam pembangunan tersebut tentunya dibutuhkan suatu perencanaan konstruksi yang tepat sehingga nyaman dan aman saat digunakan.Tanah di salah satu daerah di Mojokerto tepatnya di wilayah kecamatan "Dawarblandong" mempunyai kecenderungan memiliki sifat yang kurang baik apabila langsung didirikan bangunan di atasnya. Dampak yang kurang baik apabila tanah tersebut digunakan langsung didirikan bangunan di atasnya, diantaranyakeretakan-keretakan pada dinding dan lantai. Pada tanah yang semacam ini diperlukan adanya stabilisasi yaitu dengan memberikan material tambahan. Material kapur dapat digunakan sabagai bahan campuran untuk stabilisasi karena kapur memiliki sifat kimia yang dapat mengikat partikel - partikel tanah sehingga meningkatkan nilaiparameter tanah tersebut.

Suatu konstruksi untuk perumahan, pertokoan, perkantoran, dan gedung fasilitas umum yang terdiri dari satu sampai dengan dua lantai biasanya cukup ditopang oleh pondasi dangkal,hal ini tergantung dari jenis tanah dan nilai parameter tanah di bawahnya. Jika parameter tanah di bawah pondasi cukup kecil maka dapat dilakukan stabilisasi pada tanah tersebut pada kedalaman satu sampai dengan dua kali lebar pondasi. Peningkatan parameter tanah yang diperoleh dari stabilisasi kapur pada tanah bergantung jumlah persentase kapur tersebut pada tanah, sehingga perlu dilakukan beberapa percobaan dengan jumlah persentase kapur yang berbeda untuk dapat melihat pengaruh persentase kapur terhadap peningkatan dayadukungpondasidangkal pada tanah yang sudah distabilisasi dengan material kapur tersebut.

Parameter yang dibutuhkan untuk menganalisa daya dukung tanah meliputi berat volume tanah $(\gamma)$, sudut geser tanah $(\phi)$, dan cohesi (c). Suatu pengujian tanah untuk mendapatkan parameter sudut geser tanah dan cohesi tanah adalah uji directh shear, unconfined atau triaxial. Pengujian lainnya yang sering dilakukan untuk mengetahui karakteristik tanah adalah uji konsistensi tanah, dari pengujian ini akan di dapat parameter batas cair $(L L)$, batas plastis $(P L)$, dan indeks plastisitas $(I P)$. Namun parameter batas cair $(L L)$, batas plastis $(P L)$, dan indeks plastisitas $(I P)$ tersebut tidak bisa langsung digunakan untuk menghitung atau merencanakan pondasi dangkal sehingga dibutuhkan suatu hubungan atau korelasi antara parameter plastisitas tanah dengan parameter sudut geser tanah dan kohesi.

Permasalahan dalam penelitian ini adalah bagaimana korelasi antara parameter indeks plastisitas dengan kohesi tanah setelah diberi penambahan kapur, bagaimana korelasi antara parameter indeks plastisitas dengan sudut geser tanah setelah diberi penambahan kapur, bagaimana pengaruh penambahan kapur terhadap nilai batas cair, batas plastis dan indeks plastisitas pada tanah di daerah mojokerto tersebut, bagaimana pengaruh penambahan kapur terhadap stabilisasi daya dukung pondasi dangkal pada tanah di daerah mojokerto tersebut.

\section{METODE PENELITIAN \\ Pengambilan Sample Tanah}

Tanah yang akan digunakan sebagai benda uji di dalam penelitian ini diambil dari areaMojokertoJawa Timur. Sampel tanah yang diambil adalah tanah terganggu (disturbed soil) dan tanah tak terganggu (undisturbed soil). Kedalaman sampel tanah sekitar $1 \mathrm{~m}$ dari permukaan tanah. Sampel tanah yang diambil merupakan sampel tanah yang mewakili tanah di lokasi pengambilan sampel. Sampel tanah tersebutdigunakan untuk pengujian batas batas konsistensi tanah,volumetri gravimetri, pemadatan proctor sandartdan uji geser langsung (directh shear) pada kondisi sebelum dan sesudah distabilisasi dengan kapur.

\section{Peralatan}

Peralatan yang digunakan dalam penelitian ini adalah alat untuk uji batas batas konsistensi, volumetri - gravimetri,pemadatan proctor sandart dan uji geser langsung (directh shear) dan peralatan lainnya yang ada di Laboratorium Mekanika Tanah Jurusan Teknik Sipil, Universitas Negeri Surabaya yang telah sesuai dengan standarisasi American Society for Testing Material (ASTM).

\section{Benda Uji Tanah}

Benda uji yang digunakan pada penelitian ini adalah benda uji yang dibuatkan berdasarkan kondisi awal dari tes pemadatan proctor standart, yaitu berdasarkan nilai dari berat volume kering maksimum $\left(\gamma_{\text {dmaks }}\right)$. 


\section{Stabilitas Tanah dengan Kapur}

Stabilisasi tanah dilakukan dengan cara menambahkan mencampurkan bahan kapur ke dalam sampel tanah dengan cara sebagai berikut:

Tanah tersebut sebelum diuji, dijemur terlebih dahulu untuk memudahkan dalam proses penyaringan agar butirannya tidak melekat satu sama lain, kemudian sampel tanah yang telah ditumbuk (butir aslinya tidak pecah) dan diayak lolos saringan No. 4 (4,75 mm). Kapur yang digunakan dengan variasi kadar kapur sebesar $0 \%$, $10 \%, 20 \%$, dan $30 \%$. Tanah + kapur yang sudah tercampur lalu diperam selama 24 jam baru setelah itu dilakukan pemadatan proctor standart.

\section{Teknik Pengambilan Sample}

Teknik pengambilan sampel dalam penelitian ini dilakukan dengan pengujian di Laboratorium Mekanika Tanah Jurusan Teknik Sipil, Universitas Negeri Surabaya. Adapun pengujian-pengujian tersebut adalah sebagai berikut, pengujian yang dilakukan di laboratorium mekanika tanah meliputi, pengujian batas cair, pengujian batas plastis, Pengujian specific gravity, pengujian kadar air, Pengujian pemadatan proctor standart, pengujian geser langsung (Directh shear). Pada pengujian tanah stabilisasi setiap sampel tanah dibuat campuran dengan masing-masing variasi kadar kapur.

Berdasarkan dari hasil yang telah diperoleh dari pengujian yang dilakukan di laboratorium mekanika tanah, maka didapatkan data-data daritanah yang masihperludiolah. Dari data-data tersebut yang telah dilakukan pengolahan dan dianalisa berdasarkan teori-teori yang ada pada Bab II, maka didapatkan parameter-parameter tanah yang diperlukan dalam penelitian ini. Selanjutnya parameter-parameter tanah tersebut dianalisa secara diskriptif kualitatif dan disajikan dalam bentuk table dan grafik.

Penelitian ini dilakukan dalam beberapa tahap. Diagram alir penilitian ini dapat dilihat pada gambar 1 sebagai berikut.

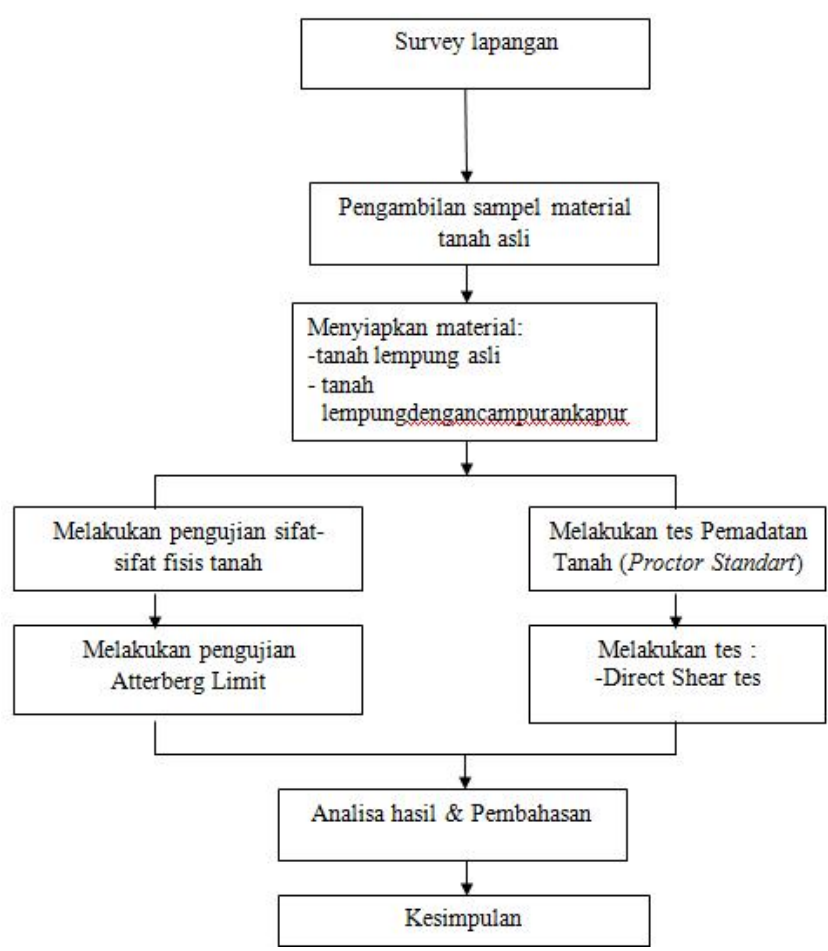

Gambar 1. Diagram Alur Penelitian

\section{HASIL DAN PEMBAHASAN}

Hasil-Hasil Pengujian Batas-Batas Atterberg dengan Penambahan Kapur

Berdasarkan hasil dari praktikum Batas - Batas Atterberg (Atterberg Limit) yang meliputi tes batas cair (Liquid Limit, LL) dan tes batas plastis (Plastic Limit, PL) pada tanah lempung ekspansif yang distabilisasi/diberi tambahan kapur dapat mengurangisifat plastisitas tanah lempung ekspansif tersebut. Hal ini bisa dilihat pada nilai batas cair (LL), batas plastis (PL) dan nilai indek Plastisitas (IP) dari tanah ekspansif tersebut. Agar lebih jelasnya hasil tes tesebut dapat dilihat pada Tabel 1 di bawah ini.

Tabel 1. Nilai Atterberg Limit Dengan Penambahan Kapur

\begin{tabular}{|c|c|c|c|c|c|}
\hline \multirow{3}{*}{$\begin{array}{c}\text { Benda } \\
\text { Uji }\end{array}$} & \multicolumn{2}{|c|}{$\begin{array}{c}\text { Campuran Benda } \\
\text { Uji }\end{array}$} & \multirow{3}{*}{$\begin{array}{l}\mathrm{LL} \\
(\%)\end{array}$} & \multirow{3}{*}{$\begin{array}{l}\text { PL } \\
(\%)\end{array}$} & \multirow{3}{*}{$\begin{array}{l}\text { IP } \\
(\%)\end{array}$} \\
\hline & \multirow{2}{*}{$\begin{array}{c}\text { Tanah } \\
\text { lempung } \\
\text { ekspansif } \\
(\%) \\
\end{array}$} & \multirow{2}{*}{$\begin{array}{c}\text { Kapur } \\
(\%)\end{array}$} & & & \\
\hline & & & & & \\
\hline 1 & 100 & 0 & 60.33 & 23.08 & 37.25 \\
\hline 2 & 100 & 10 & 52.47 & 24.35 & 28.12 \\
\hline 3 & 100 & 20 & 52.1 & 26.00 & 26.10 \\
\hline 4 & 100 & 30 & 51.31 & 27.15 & 24.16 \\
\hline
\end{tabular}

Sumber : Hasil Laboratorium

Pada tabel tersebut di atas dapat dilihat bahwa tanah lempung ekspansif yang diberi tambahan kapur berturut-turut mulai kadar $0 \%, 10 \%, 20 \%$ dan $30 \%$ 
tingkat plastisitas tanahnya mengalami penurunan. Pada tanah asli sebelum distabilisasi dengan kapur nilai LL mencapai $60.33 \%$.

\section{Hasil Pengujian Pemadatan ProctorStandart dengan Penambahan Kapur}

Pengujian pemadatan proctor standart ini digunakan sebagai kondisi awal untuk pembuatan benda uji penelitian (sampel) dengan berbagai persentase penambahan kapur. Persentase kapur yang digunakan adalah mulai dari $0 \%, 10 \%, 20 \%$ dan $30 \%$. Adapun hasil dari uji proctor standart dapat dilihat pada Tabel 2. di bawah ini.

Tabel 2. Nilai Berat Volume kering Maksimum dan Kadar Air Optimum Dengan Penambahan Kapur

\begin{tabular}{|c|c|c|c|c|}
\hline \multirow[b]{2}{*}{$\begin{array}{l}\text { Benda } \\
\text { Uji }\end{array}$} & \multicolumn{2}{|c|}{$\begin{array}{l}\text { Campuran } \\
\text { Benda Uji }\end{array}$} & \multirow[b]{2}{*}{$\begin{array}{c}\gamma_{\mathrm{dmax}} \\
(\mathrm{gr} / \mathrm{cm} 3)\end{array}$} & \multirow{2}{*}{$\begin{array}{l}\text { wc } \\
\text { opt } \\
(\%)\end{array}$} \\
\hline & $\begin{array}{c}\mathrm{T} . \\
\text { Asli } \\
(\%)\end{array}$ & $\begin{array}{c}\text { Kapur } \\
(\%)\end{array}$ & & \\
\hline 1 & 100 & 0 & 1.416 & 25.20 \\
\hline 2 & 100 & 10 & 1.445 & 22.50 \\
\hline 3 & 100 & 20 & 1.326 & 27.50 \\
\hline 4 & 100 & 30 & 1.324 & 27.20 \\
\hline
\end{tabular}

Sumber : Hasil Laboratorium

Pada tabel tersebut dapat dilihat bahwa tanah ekspansif yang diberi penambahan 10\% kapur nilai berat volume kering maksimumnya ( $\gamma d \max )$ mengalami peningkatan sebesar $2.05 \%$

Berat volume keringnya ( $\gamma d \max )$ menjadi turun karena ruang-ruang pori yang seharusnya terisi oleh butiran padat telah tergantikan oleh air. dan sebaliknya nilai kadar air optimumnya menjadi meningkat Hal ini bisa dilihat seperti pada gambar 2 di bawah ini.

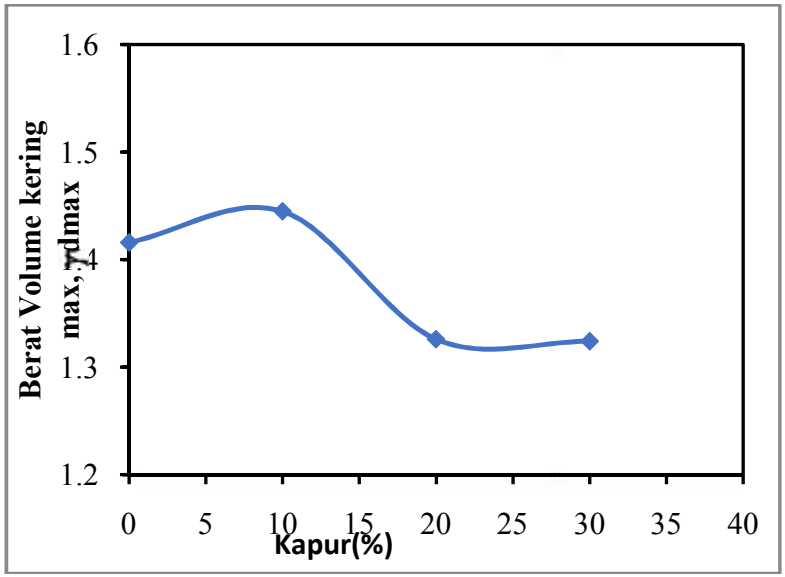

Gambar 2. Pengaruh Penambahan Kapur
Terhadap Nilai Berat Volume Kering Maximum ( $\gamma \mathrm{dmax})$

\section{Hasil Uji Parameter Kuat Geser Tanah Dengan Penambahan Kapur}

Berdasarkan hasil pengujian tes Direct Shearyang dilakukan pada benda uji dapat dilihat bahwa benda uji yang diberi tambahan kapur nilai kohesi meningkat. Benda uji diberi tambahan kapur 10\% menunjukkan terjadinya peningkatan nilai kohesi yang paling besar dibandingkan pada persentase yang lain, seperti yang terlihat pada Tabel 3, Pada tabel tersebut terlihat bahwa dengan penambahan $10 \%$ kapur nilai kohesi meningkat sebesar $15.52 \%$

Tabel 3. Nilai Kohesi Dengan Penambahan Kapur

\begin{tabular}{|c|c|c|c|c|}
\hline \multirow[b]{2}{*}{$\begin{array}{c}\text { Benda } \\
\text { Uji }\end{array}$} & \multicolumn{2}{|c|}{$\begin{array}{l}\text { Campuran } \\
\text { Benda Uji }\end{array}$} & \multirow{2}{*}{$\begin{array}{c}\text { Kohesi, } \\
\text { C } \\
(\mathrm{gr} / \mathrm{cm} 2)\end{array}$} & \multirow[b]{2}{*}{$\begin{array}{c}\text { Kenaikan } \\
(\%)\end{array}$} \\
\hline & $\begin{array}{c}\text { Tanah } \\
\text { Asli } \\
(\%)\end{array}$ & $\begin{array}{c}\text { Kapur } \\
(\%)\end{array}$ & & \\
\hline 1 & 100 & 0 & 0.290 & 0.00 \\
\hline 2 & 100 & 10 & 0.335 & 15.52 \\
\hline 3 & 100 & 20 & 0.345 & 2.99 \\
\hline 4 & 100 & 30 & 0.342 & -0.87 \\
\hline
\end{tabular}

Sumber : Hasil Laboratorium

Sehingga dapat dikatakan bahwa penambahan kapur $10 \%$ adalah yang paling efektif dapat meningkatkan nilai kohesi tanah sebesar $15.52 \%$.

Apabila kandungan kapur ditambah terus maka menyebabkantanah lempung ekspansifnya menjadi sedikit dan menyebabkan banyak rongga-rongga. Dengan demikian tanah menjadi tidak padat lagi, sehingga nilai kohesi menjadi turun. Lebih jelasnya bisa dilihat pada grafik di bawah ini.

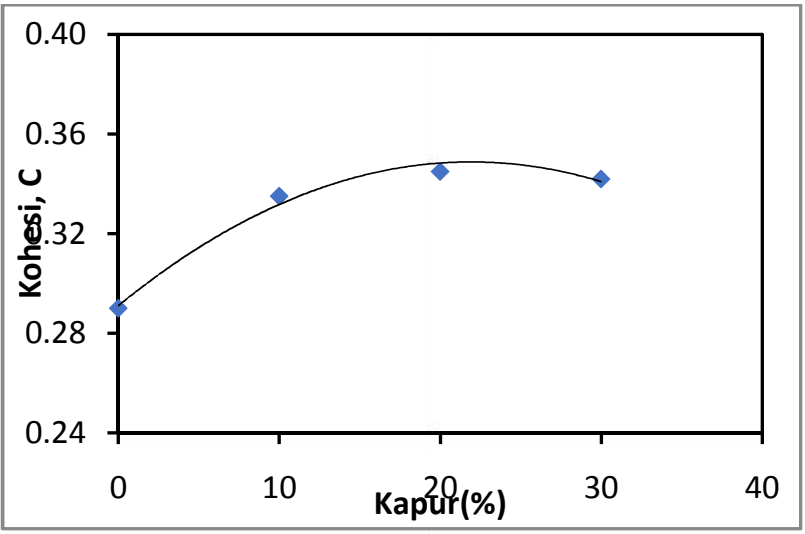

Gambar 3. Pengaruh Penambahan KapurTerhadap Nilai Kohesi Tanah 
Sebaliknya yang terjadi pada sudut geser tanah $(\phi)$, semakin banyak kapur yang ditambahkan pada tanah maka sudut geser tanah menjadi semakin kecil. Hal ini dapat dilihat pada tabel 4 dan gambar 4 berikut ini.

Tabel 4. Nilai Sudut Geser Tanah, $(\phi)$ dengan Penambahan Kapur

\begin{tabular}{|c|c|c|c|c|}
\hline \multirow[b]{2}{*}{ Benda Uji } & \multicolumn{2}{|c|}{$\begin{array}{l}\text { Campuran } \\
\text { Benda Uji }\end{array}$} & \multirow{2}{*}{$\begin{array}{c}\text { Sudut } \\
\text { geser, } \\
\square\end{array}$} & \multirow[b]{2}{*}{$\begin{array}{c}\text { Penurunan } \\
(\%)\end{array}$} \\
\hline & $\begin{array}{c}\text { Tanah } \\
\text { Asli } \\
(\%)\end{array}$ & $\begin{array}{c}\text { Kapur } \\
(\%)\end{array}$ & & \\
\hline 1 & 100 & 0 & 21.007 & -- \\
\hline 2 & 100 & 10 & 14.360 & 31.64 \\
\hline 3 & 100 & 20 & 7.632 & 46.85 \\
\hline 4 & 100 & 30 & 6.956 & 8.86 \\
\hline
\end{tabular}

Sumber : Hasil Laboratorium

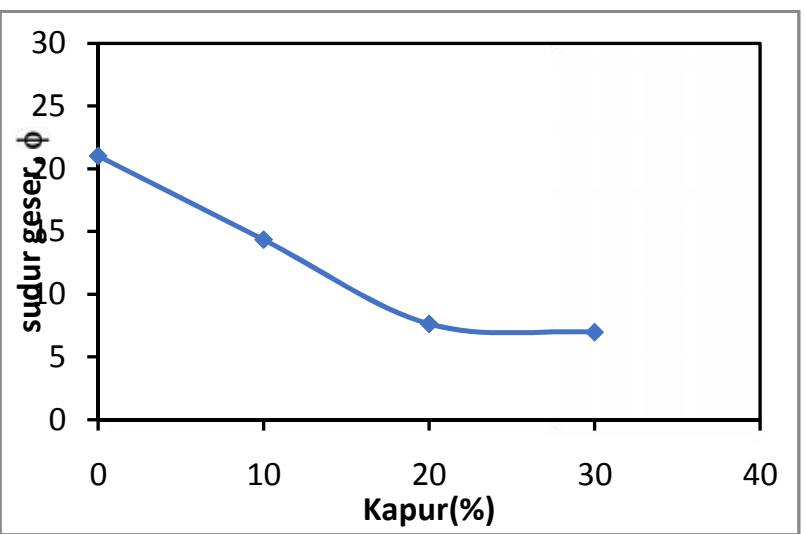

Gambar 4. Pengaruh Penambahan Kapur Terhadap Nilai Sudut Geser Tanah, $(\phi)$

\section{Korelasi antara Parameter Indeks Plastisitas dengan Parameter Kuat Geser Tanah.}

Berdasarkan dari hasil analisis yang kami lakukan terhadap hasil-hasil pengujian dari laboratorium, maka didapat bahwa ada korelasi antara parameter indeks ilastisitas tanah (IP) dengan parameter kuat geser tanah, yaitu nilai kohesi tanah (C) dan sudut geser tanah $(\phi)$, seperti yang terlihat pada gambar di bawah ini.

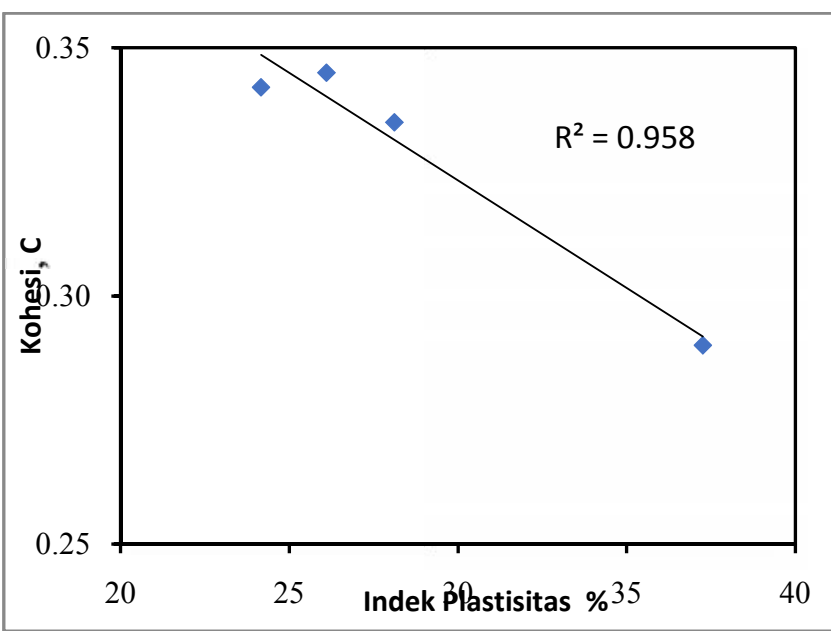

Gambar 5. Korelasi antara Indeks Plastisitas (IP) dengan Nilai kohesi Tanah (C)

Pada gambar 5 terlihat bahwa semakin besar nilai Indeks Plastisitas suatu tanah, maka semakin kecil nilai kohesi tanah tersebut. Tetapi pada gambar 6 dapat dilihat pula bahwa semakin besar indeks plastisitas suatu tanah, maka sudut geser tanah yang terjadi juga akan semakin besar pula.

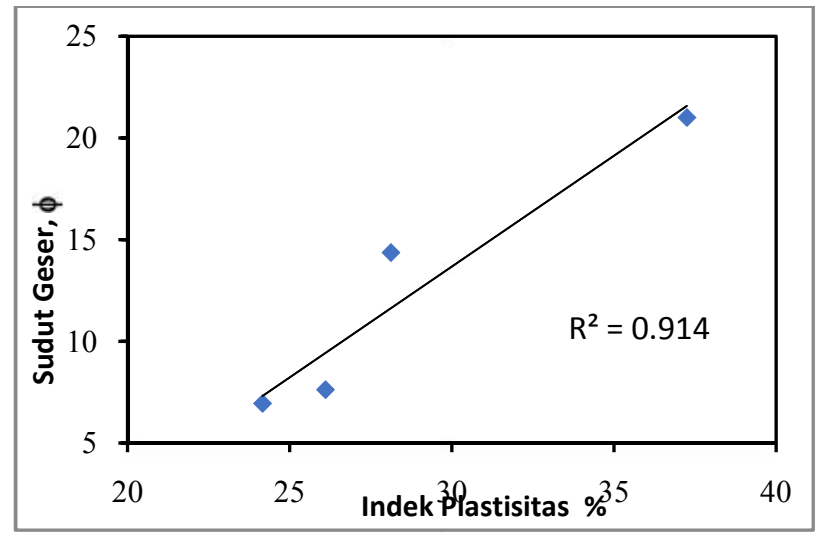

Gambar 6. Korelasi antara Indeks Plastisitas (IP) dengan Nilai Sudut Geser Tanah, $(\square)$

Hasil dapat dinyatakan dalam narasi, tabulasi, grafik, dan atau gambar. Usahakan untuk menampilkan dengan seringkas dan sekomprehensif mungkin. Pembahasan harus terfokus pada hasil dan bagaimana hasil tersebut dapat menjawab masalah yang diangkat.

\section{KESIMPULAN}

Berdasarkan dari analisis yang kami lakukan dari penelitian ini, maka dapat ditarik beberapa kesimpulan sebagai berikut, adanya stabilisasi dengan kapur pada tanah lempung ekspansif, maka terdapat Koreasi berbanding terbalik antara parameter Indeks Plastisitas Tanah dengan nilai kohesi tanah. Semakin besar Indeks Plastisitas tanah (IP), maka akan semakin kecil nilai kohesi tanahnya 
(C). Adanya stabilisasi dengan kapur pada tanah lempung ekspansif, maka terdapat Koreasi antara parameter Indeks Plastisitas Tanah dengan sudut geser tanah. Semakin besar Indeks Plastisitas tanah (IP), maka akan semakin besar pula harga sudut geser tanahnya $(\phi)$.

Semakin besar persentase kapur yang ditambahkan, maka nilai Batas Cair (LL) semakin menurun. Pada penambahan $10 \%$ kapur nilai LL menurun sebesar $13.03 \%$. Demikian pula semakin besar persentase kapur yang ditambahkan, maka nilai Indeks Plastisitas (IP) semakin menurun. Pada penambahan $10 \%$ kapur nilai IP menurun sebesar $24.52 \%$.

Adanya stabilisasi dengan 10\% kapur pada tanah lempung ekspansif di daerah mojokerto menyebabkan nilai kohesi dari tanah meningkat, maka hal ini dapat mengakibatkan stabilitas daya dukung pondasi dangka di daerah Mojokerto tersebut juga akan meningkat.

\section{REFERENSI}

Bowles, Joseph E. 1989. "Analisis Dan Disain Pondasi". Airlangga, Jakarta

CUR. 1996. "Building on Soft Soil". A.A. Balkema, Rotterdam Netherlands.

Costet. J, Sangrelat. G. 1981. "Cours Pratique de Mecanique des Sols". DUNOD, Paris.

Das, Braja M. 1995. Mekanika Tanah Jilid 1. Terjemahan Noor Endah Mochtar dan Indrasurya B. Mochtar. Jakarta: Erlangga.

Das Braja, M. 2004. "Engineering Foundation" McGraw-Hill International Editions. Washington New York London.

Hardiyatmo, Hary Christady. 2010. "Stabilisasi Tanah untuk Perkerasan Jalan". Yogyakarta: Gadjah Mada University Press.

Mitchell, James K. 1976. "Fundamental of Soil Behavior". John Wiley \& Sons, Inc, New York.

Wahyudi, H. 2002. "Swelling Soil Ditinjau Dari Aspek Mikroskopis", Makalah disampaikan pada PIT Geoteknik tanggal 30-31 Oktober 2002 di Surabaya". 